удк 37.032

Ольга Лобова

Сумський державний педагогічний університет імені А. С. Макаренка ORCID ID 0000-0001-7028-043X

Аліна Сбруєва

Сумський державний педагогічний університет імені А. С. Макаренка ORCID ID 0000-0002-1910-0138

Марина Бойченко

Сумський державний педагогічний університет імені А. С. Макаренка

ORCID ID 0000-0002-0543-8832

DOI 10.24139/2312-5993/2020.03-04/266-276

\title{
ФОРМУВАННЯ КУЛЬТУРНОЇ КОМПЕТЕНТНОСТІ ШКОЛЯРІВ У ПРОЦЕСІ МИСТЕЦЬКОÏ ОСВІТИ В «НОВІЙ УКРАЇНСЬКІЙ ШКОЛІ»
}

Статтю присвячено проблемі формування ключової культурної компетентності як одного з провідних орієнтирів Нової української школи. Метою $\epsilon$ розкриття окремих шляхів формування культурної компетентності школярів у процесі мистецької освіти. Застосовано методи аналізу й узагальнення наукових джерел, теоретичне моделювання, педагогічний експеримент тощо.

Схарактеризовано шляхи формування культурної компетентності в навчальній діяльності (за підручниками «Мистецтво» О. Лобової) та позаурочній роботі (за методикою А. Шевченко). Окреслено основні напрями підготовки майбутніх педагогів до формування культурної компетентності школярів.

Ключові слова: формування культурної компетентності, концепція "Нова українська школа», загальна мистецька освіта, дидактико-методична система, підручники «Мистецтво», вокально-джазова культура підлітків, підготовка педагогів до формування культурної компетентності учнів.

Постановка проблеми. Сучасними стратегічними орієнтирами загальної освіти в Україні є закони «Про освіту» (2017, зі змінами 2020 р.), «Про загальну середню освіту» (2020) й концепція «Нова українська школа», масове впровадження якої розпочалося з 2018-2019 навчального року. В основу цих документів покладено компетентнісний підхід, що передбачає формування у школярів низки ключових компетентностей: вільне володіння українською мовою, здатність спілкуватися рідною та однією з іноземних мов; здатність до навчання впродовж життя; математична, екологічна, інформаційно-комунікаційна компетентності тощо.

Однією з ключових визначено культурну компетентність, яка $\epsilon$ стрижневою для мистецької освітньої галузі. Формування цієї компетентності $€$ провідним завданням викладача мистецьких дисциплін, музичного мистецтва зокрема. Така місія зумовлює актуальність 
досліджень у галузі теорії та практики формування культурної компетентності учнів у сучасній українській школі.

Аналіз актуальних досліджень. Загальна освіта в Україні ґрунтується на низці нормативних документів. 14 грудня 2016 року була затверджена концепція «Нова українська школа», конструктивний аналіз якої зроблений провідними фахівцями відділу початкової освіти Інституту педагогіки НАПН України, українськими вченими та педагогами-практиками ще на етапі ії громадського обговорення (Н. Бібік, О. Онопрієнко, О. Савченко та ін.). Ідеї концепції було розвинуто в новому законі «Про освіту», прийнятому у 2017 й поновленому у 2020 році, у законі «Про загальну середню освіту» (2020) та в Державному стандарті початкової освіти, затвердженому в лютому 2018 року.

Інновацією проектів концепції Нової української школи стало застосування компетентності «загальнокультурна грамотність» або «обізнаність та самовираження у сфері культури». У попередньому стратегічному освітньому орієнтирі (Державному стандарті початкової загальної освіти 2011 року) ії аналогом була загальнокультурна компетентність, ґрунтовний аналіз якої здійснили українські вчені В. Болгаріна, С. Мельник, О. Пометун, С. Троянська та ін. Проте в законі «Про освіту» 2017 року дефініцію «загальнокультурна грамотність» було замінено на поняття «культурна компетентність». Його застосовано й у новому Державному стандарті початкової освіти.

Дослідження культурних феноменів відзначено надзвичайним розмаїттям та багатомірністю (Uvarova, 2019). У педагогіці поняття «культурна компетентність» також ще не набуло однозначного трактування. У мистецькій освіті дотичними $€$ педагогічні дослідження, спрямовані на формування окремих аспектів культурної компетентності: музичної та музично-естетичної культури (Л. Масол, Д. Кабалевський, О. Лобова, О. Ростовський, Л. Школяр та ін.); вокальної культури (Л. Гавриленко, Чжу Цзюньцяо та ін.); вокально-джазової культури (А. Шевченко) тощо. Важливою $\epsilon$ проблема підготовки майбутніх педагогів до формування культурної компетентності учнів, різні аспекти якої розкрито у працях Г. Ніколаї, О. Олексюк, Г. Падалки, О. Ребрової, М. Ткач, О. Щолокової та ін. Зокрема, питанням вокальної підготовки студентів присвячено праці Н. Овчаренко, О. Матвєєвої, О. Чеботаренко, Н. Кьон (Ovcharenko, 2019) та ін.

Аналіз наукових праць свідчить, що актуальності набуває не лише обґрунтування ключової культурної компетентності, а й дослідження теорії та практики її формування, у мистецькій освіті зокрема.

Мета статті. У зазначеному контексті метою нашої публікації $\epsilon$ розкриття окремих шляхів формування культурної компетентності школярів у процесі загальної мистецької освіти учнів в умовах Нової української школи (у навчальній і позаурочній діяльності). 
Методи дослідження. Для реалізації мети застосовано методи узагальнення наукових джерел, аналізу навчальної літератури, теоретичне моделювання, педагогічний експеримент тощо.

Виклад основного матеріалу. Нормативним підґрунтям освіти в нашій країні $€$ закони «Про освіту», «Про дошкільну освіту», «Про позашкільну освіту», «Про професійно-технічну освіту», «Про вищу освіту», «Про повну загальну середню освіту» та ін. Навчання школярів безпосередньо регламентують закони «Про освіту» (зі змінами 2020 р.), «Про повну загальну середню освіту» (2020), а також концепція «Нова українська школа» (2016).

Згідно із зазначеними документами, метою освіти $€$ всебічний розвиток людини як особистості й найвищої цінності суспільства, їі талантів, інтелектуальних, творчих і фізичних здібностей, формування цінностей і необхідних для успішної самореалізації компетентностей, виховання відповідальних громадян, які здатні до свідомого суспільного вибору та спрямування своєї діяльності на користь іншим людям і суспільству, збагачення на цій основі інтелектуального, економічного, творчого, культурного потенціалу Українського народу, підвищення освітнього рівня громадян задля забезпечення сталого розвитку України та ії європейського вибору.

За основу сучасної загальної освіти узято компетентнісний підхід, що передбачає зміщення акцентів з процесу накопичення знань, умінь і навичок у площину формування й розвитку в учнів здатності ефективно діяти і творчо застосовувати набуті знання та досвід у практичній діяльності. За концепцією «Нової української школи» вихідна категорія нашого дослідження «компетентність» тлумачиться як динамічна комбінація знань, способів мислення, поглядів, цінностей, навичок, умінь, інших особистих якостей, що визначає здатність особи успішно провадити професійну та/або подальшу навчальну діяльність.

В основу компетентнісного підходу покладено ключові компетентності, яких потребує кожна людина для особистої реалізації, розвитку, активної громадянської позиції, здатні забезпечити життєвий успіх молоді в суспільстві знань (Концепція..., 2016). Зокрема, до них віднесено: здатність спілкуватися рідною (у разі відмінності від державної) та однією з іноземних мов; математична; компетентності в галузі природничих наук, техніки і технологій; екологічна; інформаційно-комунікаційна; здатність до навчання впродовж життя; громадянські та соціальні компетентності; культурна; підприємливість та фінансова грамотність, інноваційність.

У державних документах у галузі освіти статусу ключової набула культурна компетентність, трактування якої зазнали різноманітних трансформацій. Спочатку культурна компетентність розумілась виключно в значенні належності до різних культур. Уперше цей термін було 
застосовано в медичній практиці щодо правильної постановки діагнозу та лікування іноземних пацієнтів як представників «іншої» культури. Тривалий час феномен культурної компетентності поширювався не лише на людину, а й на організації та розумівся як система цінностей і принципів, рівень навичок і знань, що уможливлюють співпрацю фірми 3 людьми різної етнічної або расової приналежності.

У сучасних інформаційних джерелах культурна компетентність ототожнюється з рівнем адаптованості людини до культурного, комунікаційного, техногенного сучасного середовища; умінням орієнтуватися в інформаційному потоці та достатньо вільно почуватися в сучасному полікультурному глобалізованому світі. Досить часто ця категорія замінюється поняттям «міжкультурна» компетентність, що тлумачиться як здатність особистості ефективно взаємодіяти з людьми, що представляють різні культури.

У педагогічних працях зустрічаємо трактування культурної компетентності як здатності індивіда до інтелектуально-розумового зростання шляхом постійного безперервного пізнання нового та вивчення культурної спадщини попередників, їх мудрості та культурних цінностей, а також наявності навичок спілкування та взаємодії з людьми, що належать до різних культур (Гусєва, 2018).

У чинному Державному стандарті початкової освіти та типових освітніх програмах визначення культурної компетентності не наводиться (Державний стандарт, 2018; Типові програми, 2018). Водночас, зазначено, що ця компетентність передбачає залучення учнів до різних видів мистецької творчості (образотворче, музичне та інші види мистецтв) шляхом розкриття й розвитку природних здібностей, творчого вираження особистості.

У концепції Нової української школи знаходимо трактування ключової компетентності «обізнаність та самовираження у сфері культури», що тлумачиться як здатність розуміти твори мистецтва, формувати власні мистецькі смаки, самостійно виражати ідеї, досвід та почуття за допомогою мистецтва. Ця компетентність передбачає глибоке розуміння власної національної ідентичності як підґрунтя відкритого ставлення та поваги до розмаїття культурного вираження інших (Концепція..., 2016).

Ґрунтуючись на сучасних підходах, ключову культурну компетентність школяра можна розглядати як інтегроване особистісне утворення, що поєднує знання, погляди, цінності, уміння та навички у сфері національної та світової культури, спроможність сприймати, на доступному рівні аналізувати й оцінювати культурні феномени, практично застосовувати набутий досвід культурної діяльності в житті. Формування культурної компетентності школярів у мистецькій освіті можемо визначити як спеціально організований, цілеспрямований процес опанування дитиною знань, умінь і навичок, цінностей і досвіду культурної діяльності засобами мистецтва (у навчальній і позаурочній роботі). 
Реалізація культурного компонента освіти $\epsilon$ одним із провідних завдань викладача художньо-естетичних дисциплін, зокрема, учителя музики, у праці якого цей напрям набуває актуального та цілком реального наповнення. На наш погляд, феномен культурного виховання учнів стосується, насамперед, розширення меж власне музичного виховання на загальномистецькі обрії, що передбачає:

- формування в дітей потреб у мистецтві, культурі як невід'ємній, необхідній та прекрасній частині людського життя;

- виховання любові до національної культури засобами ознайомлення школярів із народним, класичним і сучасним мистецтвом України;

- формування «мистецько-інтернаціональних» якостей через залучення дітей до найкращих надбань світової культури;

- становлення культури сприймання й розуміння творів різних видів мистецтва (літературного, образотворчого, театрального тощо);

- прийняття та застосування в житті культурних надбань, національних і загальнолюдських культурних цінностей тощо.

Основними векторами формування культурної компетентності школярів у мистецькій освіті можна виділити:

1) національний, що передбачає опанування культурної спадщини, традицій та цінностей рідного народу;

2) інтеркультурний, спрямований на розуміння, осягнення та прийняття культурних традицій, цінностей і феноменів інших народів.

Розглянемо можливості формування ключової культурної компетентності у навчальній діяльності, зокрема за підручниками Ольги Лобової «Мистецтво» для 1-3 класів, що є переможцями Всеукраїнських конкурсів підручників і видані за державним замовленням для учнів закладів загальної освіти (Лобова, 2018; 2019; 2020).

Представлена в підручниках дидактико-методична система передбачає формування таких складників культурної компетентності:

1. Формування культурної спрямованості учнів (усвідомлення цінності культури в житті людини; інтерес до освоєння культурних цінностей у процесі пізнання мистецтва; плекання позитивного ставлення та пошани до культурної спадщини рідного та інших народів). Відповідні функції підручника реалізуються через низку завдань, що допомагають дитині усвідомити роль культури та мистецтва у власному та суспільному житті, сприяють розвиткові потреб у спілкуванні з мистецтвом, художніх смаків та культурно-ціннісних орієнтацій. Навчально-методичний апарат підручника розроблено так, щоб постійно підтримувати увагу та стимулювати пізнавальну діяльність школярів. Цьому сприяють спонукальні формулювання навчальних завдань, а також подання матеріалу у формі гри, з використанням казкових образів, ребусів, головоломок, кросвордів. Зміст підручника надає можливість кожній дитини проявити себе і досягти успіху в різних видах мистецької діяльності. 
2. Формування культурної обізнаності націлено на інтегроване опанування теоретичних і практичних основ культури й відбувається в тісному зв'язку з практичною діяльністю. На становлення цього складника спрямовано навчальну інформацію щодо національної та світової культури, специфіки різних видів мистецтв, формування навичок розуміння та первинного аналізу літературних, візуальних, сценічних творів; використання народних і авторських, літературних і живописних творів; різні види мистецької діяльності, домінувальними серед яких $€$ сфери музичного та образотворчого мистецтв. Зміст кожної чверті завершено блоком завдань для тематичного контролю, а рубрика «Твої мистецькі канікули» містить пропозиції щодо організації культурної діяльності дітей у вільний час.

3. Розвивальний компонент дидактико-методичної системи спрямовується на культурний, музичний та художній розвиток дитини, розширення культурного світогляду, формування загальнокультурного мислення, мовлення тощо. Пріоритетним $€$ творчий розвиток дітей, тож у всіх видах діяльності передбачено завдання креативного типу: ритмічні, вокальні, пластичні імпровізації; різні види малювання, ліплення, аплікації; театралізація музичних творів тощо. Наприклад, у темі, присвяченій театру, дітям запропоновано розіграти виставу за піснею «Два півники», виконати в ролях пісню «Ходить гарбуз по городу», на прикладі цієї пісні придумати й, за бажанням, виготовити фігурки для пальчикового театру. Урахування різних рівнів розвитку учнів забезпечується різноманітністю навчального матеріалу, наявністю завдань на вільний вибір.

4. Виховний компонент спрямовано на становлення потреби в музичному самовдосконаленні, на формування культури спілкування 3 мистецтвом в умовах урочної та дозвіллєвої діяльності, культури поведінки в театрі, музеї тощо. Також передбачено вплив на моральне, емоційноестетичне, комунікативне, трудове, екологічне, національно-патріотичне та інтернаціональне виховання школярів.

Багато завдань націлені на ознайомлення дітей із національним фольклором і творчістю українських митців, культурними традиціями та пам'ятками нашої країни тощо. Наприклад, у рубриці «Твої мистецькі канікули» другокласникам запропоновано ознайомитися з українськими традиціями зимових свят та здійснити «віртуальну подорож» театрами різних міст України.

У змісті підручників для учнів початкової школи представлено низку фольклорних творів для слухання та виконання: народних танців (гопак, козачок, метелиця, аркан, коломийка), поспівок і пісень (дитячих, жартівливих, побутових, дум, колядок, щедрівок, веснянок тощо). Під час ознайомлення 3 цими творами відбувається не лише поступове опановування школярами знань про види та жанри вітчизняного фольклору, а й формуються почуття любові до національної культури та поваги до народу, що зміг створити і зберегти скарбницю таких непересічних цінностей. 
Принагідно подаються різноманітні відомості щодо історії фольклорного мистецтва, національних музично-культурних традицій тощо. Так, ознайомлення другокласників із українським народним танцем «Аркан» передбачає не лише аналіз власне музичних аспектів твору (характеру музики, інструментів для виконання), а й розповідь про історію виникнення танцю, розгляд національного вбрання виконавців, наслідування танцювальних рухів за поданим у підручнику зразком.

Суттєвого виховного значення в змісті музичної освіти школярів набуває ознайомлення 3 кобзарським мистецтвом - його історією, жанровими особливостями, зразками творів, постатями видатних кобзарів.

Паралельно з фольклорним аспектом, протягом усього терміну навчання в початкових класах, відбувається послідовне ознайомлення 3 професійною музикою України: відомостями про життя і творчість провідних представників національного музичного мистецтва (М. Лисенка, К. Стеценка, М. Леонтовича, Л. Ревуцького, В. Косенка та ін.), вокальними й інструментальними творами сучасних українських композиторів.

Реалізація інтеркультурного компонента загальної мистецької освіти відбувається через залучення дітей до найкращих надбань народної та професійної світової культури. При цьому вважаємо доцільним не обмежуватися мистецтвом кількох обраних країн, а надавати учням можливість ознайомитися з культурою широкого кола країн близького й далекого зарубіжжя.

Передумовами «музично-інтернаціонального» виховання школярів $\epsilon$ ознайомлення з піснями, танцями та мистецькими традиціями різних народів, з життям і творчістю видатних діячів світової музичної культури. Зокрема, у нових підручниках для початкової школи запропоновані для розучування зразки білоруського («Савка та Гришка»), польського («Зозуля»), чеського («Полька»), латиського («Ой-я, жу-жу»), естонського («У кожного свій музичний інструмент»), французького («Танець каченят», «Пастуша пісня»), бразильського («Потяг»), норвезького («Камертон») дитячого фольклору.

Протягом усього курсу навчання музики школярі дізнаються про життя і творчість видатних представників світової музичної культури (Й. С. Баха, В.А. Моцарта, Л. Бетховена, Е.Гріга, Ф.Шопена та ін.), принагідно ознайомлюючись із мистецтвом і культурними традиціями відповідних країн та епох. Виховна мета означених напрямів навчальної роботи - розвиток інтересу та поваги до мистецтва інших країн - $\epsilon$ важливою не лише в загальнокультурному контексті. На наш погляд, вона $€$ кроком до поступового прищеплення дитині інтернаціональних почуттів, підготовки до життя в глобалізованому середовищі, а також своєрідною «профілактикою» гостроактуальної в сучасному суспільстві проблеми расизму тощо. 
Інтеркультурне виховання дітей засобами мистецької діяльності відбувається не лише на шкільних уроках мистецтва. Прикладом реалізації цього напряму в позаурочній роботі сучасної школи (у також у школах мистецтв) є методика формування вокально-джазової культури підлітків на заняттях з естрадного співу, розроблена викладачем Сумської дитячої школи мистецтв № 1 Анастасією Шевченко.

Як зазначається, спів традиційно є провідною формою музичної діяльності школярів у закладі загальної освіти. Про його значення в українській школі свідчить факт, що в XX столітті протягом тривалого часу шкільний предмет мав назву «Співи». Наразі вокальна культура трактується не лише як комплексна підготовленість людини в галузі співу, а й як невід'ємна частина музичної культури особистості. Тож учитель музичного мистецтва має бути різнобічно підготовлений до організації вокальної роботи зі школярами, що передбачає оволодіння і власною співочою культурою, і методичним арсеналом навчання дітей співу (Лобова, 2017).

У контексті дослідження А. Шевченко вокально-джазова культура трактована як складна інтегрована якість особистості, що визначається гармонійним поєднанням умотивованості і здібностей, знань, умінь і навичок виконавця в галузі джазового співу та $є$ важливою умовою успішної вокальноджазової діяльності. Компонентами вокально-джазової культури підлітків визначені мотиваційно-ціннісний; компетентнісно-когнітивний; особистіснорозвивальний та виконавсько-творчий (Шевченко, 2019).

Методологічну основу методики становлять системно-структурний, особистісно-розвивальний, діяльнісний, компетентнісний і культурологічний підходи. 3 ними пов'язано комплекс запропонованих дидактичних принципів (систематичності й послідовності, наочності, урахування вікових та індивідуальних особливостей, принцип єдності художньо-емоційного і технічного, принцип комплексного формування вокально-джазової культури).

У дослідженні виділено дві групи методів формування вокальноджазової культури підлітків: загальні вокально-педагогічні методи (концентричний; пошуковий; фонетичний; уявного або внутрішнього співу; порівняльного аналізу) та спеціальні методи формування вокально-джазової культури: «слухацько-джазова скарбничка» (накопичення музично-слухового досвіду в галузі джазової музики, аналіз і порівняння вокальних мотивів та імпровізацій джазових виконавців - слухання, аналіз, підбір на слух, копіювання голосом); технічні вокально-джазові вправи (метроритмічні вправи на розвиток чуття ритму джазових творів («Scat drums» та ін.), поспівки для виховання базових елементів джазового співу); творчі вокально-джазові завдання (інтерпретація та імпровізація у джазовому стилі) (Шевченко, 2019).

Висновки та перспективи подальших наукових розвідок. Згідно 3 сучасними вимогами, стрижневим напрямом загальної мистецької освіти 
визначено формування ключової культурної компетентності школярів інтегрованого особистісного утворення, що поєднує знання, погляди, цінності, уміння та навички у сфері національної та світової культури, спроможність сприймати, на доступному рівні аналізувати й оцінювати культурні феномени, практично застосовувати набутий досвід культурної діяльності в житті.

Формування ключової культурної компетентності відбувається в навчальній і позаурочній діяльності. У першому випадку засобами організації цього процесу можуть бути шкільні підручники. Зокрема, у підручниках «Мистецтво» Ольги Лобової представлена дидактико-методична система, що передбачає цілісне формування складників культурної компетентності учнів: культурної спрямованості, обізнаності, розвиненості і вихованості. У процесі роботи з підручниками відбувається вплив на національний та інтернаціональний вектори культурної компетентності учнів.

Прикладом реалізації інтеркультурного напряму в позаурочній роботі сучасної школи (а також у школах мистецтв) є методика формування вокально-джазової культури підлітків на заняттях з естрадного співу, розроблена Анастасією Шевченко. Запропоновані в ії контексті наукові підходи, дидактичні принцип, етапи та методи формування вокальноджазової культури підлітків довели свою ефективність у процесі використання на заняттях 3 естрадного співу в музичних школах і позаурочній роботі закладів загальної освіти.

Ознайомлення 3 запропонованими шляхами культурного становлення школярів у навчальній і позаурочній роботі сприятиме вдосконаленню професійно-педагогічної підготовки майбутніх учителів до формування культурної компетентності учнів. Цей напрям вважаємо перспективним для подальших досліджень.

\section{ЛІТЕРАТУРА}

Гусева, О. (2018). Культурна компетентність учителя. Retrieved from: https://vuzlit.ru/345129 (Husieva, O. Teacher's cultural competence. Retrieved from: https://vuzlit.ru/345129).

Державний стандарт початкової освіти. Режим доступу: https://www.schoollife.org.ua. (State standard of elementary education of the school. Retrieved from: https://www.schoollife.org.ua).

Концепція реалізації державної політики у срері реформування загальної середньої освіти "Нова українська школа" на період до 2029 року. Режим доступу: https:// www.kmu.gov.ua/ua/npas/249613934. (Concept of realization of state policy in the sphere of reforming of general secondary education "New Ukrainian School" for the period till 2029. Retrieved from: https:// www.kmu.gov.ua/ua/npas/249613934).

Лобова, О. (2018). Мистецтво: підручник інтегрованого курсу для 1 класу закладів загальної середньої освіти. Київ: Школяр (Lobova, О. (2018). Arts: an integrated course textbook for 1 grade of general secondary education institutions. Kyiv: Shkoliar).

Лобова, О. (2019). Мистецтво: підручник інтегрованого курсу для 2 класу закладів загальної середньої освіти. Київ: Школяр (Lobova, О. (2019). Arts: an integrated course textbook for 2 grade of general secondary education institutions. Kyiv: Shkoliar). 
Лобова, О. (2020). Мистецтво: підручник інтегрованого курсу для 3 класу закладів загальної середньої освіти. Київ: Школяр (Lobova, О. (2020). Arts: an integrated course textbook for 3 grade of general secondary education institutions. Kyiv: Shkoliar).

Лобова, О. В. (2017). Педагогічні основи музично-хореографічної підготовки майбутніх вихователів дошкільних навчальних закладів. Педагогічні науки: теорія, історія, інноваційні технологіï, 8 (72), 12-23 (Lobova, O. V. (2017). Pedagogical bases of musical and choreographic preparation of future educators of preschool educational institutions. Pedagogical sciences: theory, history, innovative technologies, 8 (72), 12-23).

Типові освітні програми. Режим доступу: https://mon.gov.ua/ua (Typical educational programs. Retrieved from: https://mon.gov.ua/ua).

Шевченко, А. С., Лобова, О. В. (2019). Методика формування вокально-джазової культури підлітків на заняттях з естрадного співу. Науковий вісник Південноукраїнського національного педагогічного університету імені К. Д. Ушинського, 2 (127), 80-87 (Shevchenko, A., Lobova, O. (2019). Methodology of teenagers' vocal-jazz culture formation at pop singing lessons. Scientific Bulletin of the South Ukrainian National Pedagogical University named after KD Ushinsky, 2 (127), 80-87).

Ovcharenko, N., Matveieva, O., Chebotarenko, O., \& Koehn, N. (2019). Methodological Readiness of Musical Art Master's Degree Students: A Theoretical Research. Journal of History Culture and Art Research, 8 (4), 166-176. doi: http://dx.doi.org/10.7596/taksad.v8i4.2285.

Uvarova, T. (2019). Cultural Multidimensionality in Research Practices. Journal of History Culture and Art Research, 8 (2).

\section{PEЗЮME}

Лобова Ольга, Сбруева Алина, Бойченко Марина. Формирование культурной компетентности школьников в процессе художественного образования в «Новой украинской школе».

Статья посвящена проблеме формирования ключевой культурной компетентности как одного из ведущих ориентиров Новой украинской школы. Цель статьи - раскрыть отдельные пути формирования культурной компетентности школьников в прочессе художественного образования. Использованы методы анализа и обобщения научных источников, теоретическое моделирование, педагогический эксперимент и др.

Охарактеризованы пути формирования культурной компетентности в учебной деятельности (по учебникам «Искусство» О. Лобовой) и внеурочной работе (по методике А. Шевченко). Определены основные направления подготовки будущих педагогов к формированию культурной компетентности школьников.

Ключевые слова: фрормирование культурной компетентности, концепция «Новая украинская школа», общее художественное образование, дидактикометодическая система, учебники «Искусство», вокально-джазовая культура подростков, подготовка педагогов к формированию культурной компетентности учащихся.

\section{SUMMARY}

Lobova Olga, Sonuieva Alina, Boydhenko Marina. Formation of schoolchildren's cultural competence in the process of art education in the «New Ukrainian School».

The article is devoted to the topical issue of key cultural competence formation as one of the leading landmarks of the New Ukrainian School. The purpose of the study is to reveal some ways of schoolchildren's cultural competence formation in the process of general art education. In the study the methods of generalization of scientific sources, analysis of educational literature, theoretical modeling, pedagogical experiment, etc. have been used. 
According to modern requirements, the core direction of general art education is formation of schoolchildren's key cultural competence - an integrated personal entity that combines knowledge, attitudes, values, skills and competences in the field of national and world culture, ability to perceive, analyze and evaluate cultural phenomena at an accessible level, use acquired cultural activity experience in everyday life.

Formation of key cultural competence occurs in educational and extracurricular activities. In the first case, the textbooks are the means of organizing this process. In particular, Olga Lobova's "Art" textbooks present a didactic-methodological system that provides for the holistic formation of the components of pupils' cultural competence: cultural orientation, awareness, development and upbringing. While working with textbooks, the national and international vectors of pupils' cultural competence are influenced.

An example of implementation of intercultural direction in the extracurricular work of the modern school (also in art schools) is methodology of teenagers' vocal-jazz culture formation at pop singing lessons, developed by Anastasia Shevchenko. Proposed in its context scientific approaches, didactic principle, stages and methods of teenagers' vocal-jazz culture formation have proved their effectiveness in the process of implementation at pop singing lessons in music schools and extra-curricular work of general education institutions.

Acquaintance with proposed ways of schoolchildren's cultural competence formation in educational and extra-curricular work will help improve future teachers professional and pedagogical training in the aspect of pupils' cultural competence formation.

Key words cultural competence formation, concept of "New Ukrainian School", general art education, didactic and methodological system, textbooks "Art", vocal-jazz culture of teenagers, teachers preparation for the formation of pupils' cultural competence.

\title{
UDC37.013:793.3
}

\author{
Olena Moskalenko \\ National Aviation University \\ ORCID ID 0000-0003-3182-6801 \\ Oleksandr Skypnyk \\ NFA Kropyvnytskyi \\ ORCID ID 0000-0001-5417-8953
}

DOI 10.24139/2312-5993/2020.03-04/276-290

\section{EXPERIMENTAL VERIFCATION OF THE ETIOENCY OFTHESTRUCTURAL- FUNCTIONAL MODE OF FORMATION OF PERSONAL-PROFESSONALIMAGE OFFUTURE CHOREOGRAPHYTEAOHERS}

In the article the author analyzes experimental verification of the effectiveness of the structural-functional model of the formation of personal and professional image of future teachers of choreography in the process of professional training. The author considers professional image of a future choreography teacher as a holistic image of a teacher, which is a harmonious combination of his/her unique external and internal and personalprofessional qualities, life positions, professional knowledge and choreographic skills, which emphasize the unique personality of the future teacher and have a significant impact on the professional functions in the field of choreography. Indicators and criteria for the formation of the professional image of the future teacher of choreography are determined.

Key words professional image, future choreography teacher, levels, indicators and criteria of formation, experimental verification. 